\title{
Mergers, Acquisitions, and Corporate Financial Performance in the Financial Technology Inclined Quoted Insurance Companies in Nigeria
}

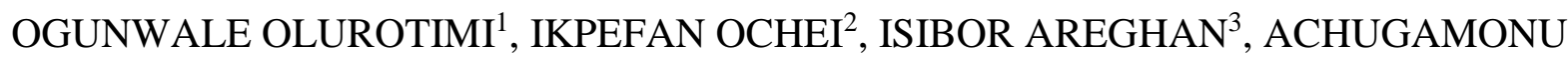 \\ UZOMA $^{4}$, FOLASHADE OWOLABI $^{5}$, OSUMA GODSWILL ${ }^{6}$, ADEBAYO MERCY $^{7}$ \\ $1 \& 5$ Department of Accounting, Covenant University, Ota, NIGERIA \\ 2, 3, 4, \& 6 Department of Banking and Finance, Covenant University, Ota, NIGERIA \\ ${ }^{7}$ Department of Sociology, Covenant University, Ota, NIGERIA
}

\begin{abstract}
The research empirically examines effect of Mergers and Acquisitions on Corporate Financial success of Quoted Insurance Companies in Nigeria. It has become expedient in the face of the drastic increase in Mergers and Acquisitions activity in recent decades and the fact that there has been very little empirical evidence of positive wealth effects and particularly the success of M\&A in the insurance sector. This has arisen because most studies in Nigeria have rather focused on the banking sector. Data was obtained from Quoted Insurance Companies from 2003 to 2016 and the Regression Techniques were employed in the study. The result indicated that there exists a positive effect of M\&A on Corporate Financial Performance of Insurance Companies. It revealed that a unit increase in merger led to about $4 \%$ increase in the Corporate Financial Performance of the merged firms. In effect, a unit increase in Earnings after Merger actually led to about $8 \%$ increase in the Corporate Financial Performance of the same firms. The study hereby recommend that Insurance Companies should look at issues of Claims settlement, Product Development and Branding while the National Insurance Commission (NAICOM) should look into the education of insurable clients as well as appropriate polices that would drive Insurance penetration in Nigeria.
\end{abstract}

Key-words:- Corporate financial performance, Financial Technology, Insurance, Mergers and acquisitions, Nigeria

Received: December 8, 2020. Revised: April 23, 2021. Accepted: May 2, 2021. Published: May 9, 2021.

\section{Introduction}

In September 2005, the Federal Government of Nigeria unfolded a reform package requiring an 18-month recapitalization period for the Insurance companies in Nigeria. This meant that between September 8, 2005 and February 28, 2007, all the Insurance companies had to meet the new requirements [1]. This circumstance followed the Banking consolidation exercise vis-à-vis an attempt by the Nigerian
Government to build a strong Financial System. Further to this, Life-insurance businesses are to recapitalize from 150 million naira to 2 billion naira whereas, Composite insurance businesses (these are Companies that operate both Life \& Nonlife Insurance Businesses) increased theirs to 5 billion naira.

This regulatory requirement drove the Nigerian Insurance Companies to consolidate their businesses through mergers and acquisitions [2], [27], and [28]. 
Imperatively, this has aligned with the quest for rapid growth by companies as a result of emerging global and at various times, regulatory requirements including the desire for profitability, sustainability, development of a dominant position in areas where they operate. For the past twenty years, because of industrial developments, globalization, liberalization, and business environment that become extremely competitive, mergers and acquisitions have become trendy all over the globe [4], [10], [23]. This portends that mergers and acquisitions have become foreseeable for businesses to utilize.

One of the ponderous benchmarks for evaluating performance of an economy is through the production levels over a specific measure of chronology. Economic growth, as a macroeconomic policy objective is a key indicator of how healthy or not, an economy is. When it comes to improving the general living standards and reducing poverty levels, most especially, in developing countries, economic growth is one of such important tools utilized [16], [18]. Economic growth poses as an indispensable factor for economic development. Economic growth transforms societies by lowering inequality levels; creates job opportunities leading to higher demand for labour; and drives human development by increasing the ability of people to pay for necessary goods and services. It is indomitably presumed sureenough that the preeminent antecedents arousing economic aggrandizement are capital, labour and technology which is exogenously determined [14], [39], [20].

For contemporary business environment, financial ratio analysis is used as the key performance measure to ascertain whether the business is viable as many business organizations consider profitability as the measure of their corporate financial performance. Profit margin, which measures how much money the firm makes after deducting the direct costs of sales; the earnings before interest and tax (EBIT) margin as well as return on capital employed (ROCE). In light of the colossal economic value and the soaring level of universal activity services particularly the insurance sector, a small number of studies on the subject matter, has addressed the financially viable justifications and effects of these M\&A deals. From a theoretical perspective, various academic point of view and rationales for value creation in M\&A [3], [7], [10], as well as motives for insurance M\&A, are addressed in the existing literature. Interestingly, in spite of this theoretical reason and the far-reaching increase in M\&A activity in the last ten (10) years, there has been little empirical substantiation of positive wealth effects and the success of M\&A in the insurance sector. This is because most studies in Nigeria have rather focused on the banking sector [33], [22], [39]. Besides, studies in $\mathrm{M}$ and $\mathrm{A}$ dealings in banking industry frequently doubts value formation or even detects value devastation in the course of this form of external streamlining.

The imperativeness for the recapitalization or new capital base included the need for Insurance penetration relative to the altitude of capitalization emergent economies concentration and budding businesses [38], [41], [42]. This now required operators in the industry to shore-up their capital through provision of new capital or a via business combination which the led to mergers and acquisitions in the industry. The private sector investors in any country are expected to have moved from analog to digital system in all aspects of their operation including communication with their bankers. This is important so as to smoothen their financial operations and avoid delays in their financial dealings with their bankers. Where there is absence of digitalization in the private sector, there will be lower output and 
performance [32] and [44] because of inconsistent and delay in the supply of credit from financial institutions on request. Some relevant studies can be found in [46], [47], [48].

\section{Theoretical Review \\ 2.1 Efficiency Theory}

This theory suggests that growth that acts as a stimulant for the advancement of the financial sector and not vice versa [14] and [15]. It postulates a causal relationship intervening finance and growth. This hypothesis states that growth is what generates amplifies requisition for financial services. The debate on the demandfollowing hypothesis originated from the works of Robinson (1952) that altercated growth as not being exerted by any causal impact [45] and [18], instead, finance goes ahead of economic growth as a turn-out of a surge in request for loans. As economies advances, plenty financial intermediaries spring up, thereby leading to an upsurge in request for financial products and services. Findings revealed financial and economic advancement as being correlated positively over the specified period. He stressed that financial development, to a large extent, performs better in the beginning phase of economic advancement when nations have crouched stratum of earnings. Findings from the study also revealed that as countries continued to develop, the size of financial institutions grew. Some proponents of the demand-following hypothesis are [30], [27], [34], and [35] whose findings all support the demand-following phenomenon.

\section{Model Specification}

For the study, a panel data research method will be used for the 15 insurance listed firms from 2003 to 2016 by means of a Least
Squares Regression Analysis. This model describes the relationship between corporate financial performance and mergers and acquisition variables based on the selected theory explained in the previous section.

$P E R F_{i t}=f$ (Earnings, size, merger, reputation)......

This is expressed implicitly as

$P_{\text {ERF }}=\beta_{0}+\beta_{1}$ LOGGROSSPRE it + $\beta_{2}$ MERGE $_{i t}+\beta_{3}$ CLAIM $_{i t}+\beta_{4}$ FSIZE $_{i t}+\varepsilon_{i t}$ ..... (2)

Where:

PERF $=$ Corporate financial performance

LOGGROSSPRE = Natural Log of gross premium

MERGE = "dummy variable" to differentiate period of merger/acquisition

CLAIM = claims against the insurance companies

FSIZE $=$ Firm size

$\varepsilon_{i t}$ is the white noise

$\beta_{0}$ represents constant variable

$\beta_{1, \ldots,}, \beta_{5}=$ coefficients of the variables

$\mathrm{i}=1, . ., 15$ is the company identifier

$\mathrm{t}=1, \ldots, 5$ is the time dimension

The a priori expectation is $\beta_{1}, \beta_{2}$, and $\beta_{4}>0$, $\beta_{3}<0$. That is, gross premium, merger and firm have a positive effect on corporate financial performance and vice-versa. Claim has a negative effect on corporate financial performance such that as claims increases corporate financial performance decreases and vice-versa.

\subsection{Data Sources}

This study used secondary data gotten from the Nigeria Insurance digest, NSE fact books, and annual reports of the selected companies covering the period under review. Also, a total of Fifteen (15) companies were used for this study. The companies used were Custodian and Allied plc, Equity Assurance plc, Great Nigeria Insurance plc, Guinea Insurance plc, Law Union and Rock Insurance, Regency Alliance Insurance, General Insurance, UNIC Diversified Holdings, Universal 
Insurance Company Plc, and Veritas Kapital Assurance Plc.

The method of analysis was Regression Techniques and the E-View software was used to run the analysis. Regression analysis is known to be a statistical forecasting model that is concerned with relating and forming an opinion of relationship connecting given variables.

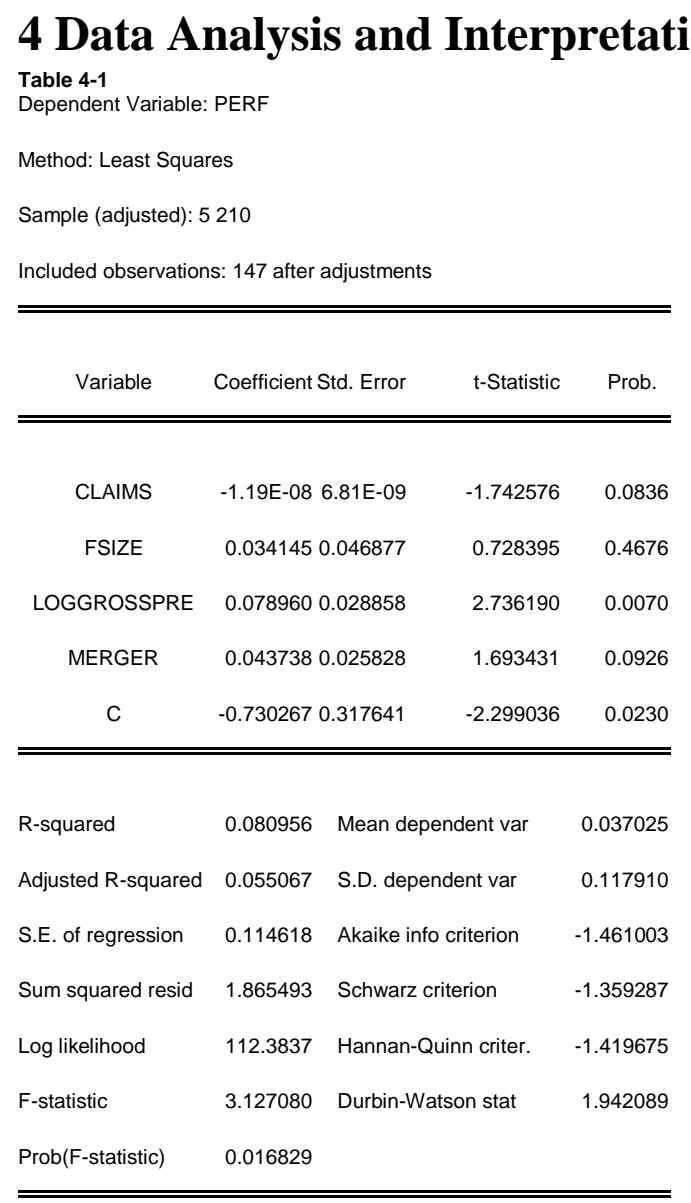

The regression result is presented in Table 4.3 above. The Adjusted R-squared value of 0.055067 indicates that about $6 \%$ systematic cross-sectional variation in financial performance of merge firm is accounted for by the independent variables of claims, earnings, firm size and merger. The robust fstat of 3.127080 indicates a significant effect between the dependent variable and explanatory variables. The Durbin-Watson statistic 1.942089 is not substantially different from the 2.00 benchmark and indicative of the absence of the problem of multicollinearity.

Claims reported a negative coefficient of 1.19E-08 and a robust t-value of -1.742576 . This implies claims will lead to a decrease in finances of merge firm.

Merger showed a positive relationship with financial performance as t-value was 1.693431. It means as the firm merge, there will be an increase in the finances of the merge companies. For individual significance only earnings (LOGGROSSPRE) showed a significant relationship with financial performance with a t-value of 2.736190 at $5 \%$ level of significance, while an insignificant relationship existed between claims. Firm size and merger with financial performance had a t-value of $-1.742576,0.728395$ and 1.693431 respectively.

\section{Recommendations}

1. It is expedient that insurance companies should deepen their technical expertise to enable them participate in the more lucrative markets of Agricultural Insurance, Oil \& Gas as well as Aviation. Most of the businesses in these areas are ceded to Companies overseas. Therefore, as they process new businesses from this captive markets, gross premium would increase.

2. The Insurance Companies should look at branding and product development as important in driving high volumes of insurance business. This would lead to increase in net earnings arising from growth in gross premium. Similarly, net earnings would also receive boosts from anticipated increase in investment incomes arising from increase in insurance funds available for investment.

3. Claims payment is a necessity for growth of the Insurance Industry in Nigeria. While underwriting capacity, that is financial 
ability, is of a major requirement of regulatory authorities, in this case, the National Insurance Commission (NAICOM), it is important also to push insurance education within the populace. The need to educate the larger uninsured population is germane to building a virile Nigerian insurance industry.

\section{Acknowledgment}

The researchers wish to thank Covenant University for their unwavering support towards the sponsorship of this research article.

\section{References}

[1] Ahmed, M., \& Ahmed, Z. Mergers and Acquisitions: Effect on financial performance of manufacturing companies of Pakistan. Middle East Journal of Scientific Research, Vol. 21, No. 4, 2014, 706-716.

[2] Al-Hroot, Y. A. The impact of mergers on financial performance of the Jordanian industrial sector. International Journal of Management \& Business Studies, Vol. 6, No. 1, 2016, 2230-9519.

[3] Babajide AA, Adedoyin L,Umoren G,Isibor AA, Financial inclusion in Nigeria: Prospect, issues and challenges. Proceedings of the 33rd International Business Information Management Association Conference, IBIMA 2019: Education Excellence and Innovation Management through Vision 2020.

[4] Al-Sharkas A, Hassan M. K and Lawrence $\mathrm{S}$. The impact of mergers and acquisitions on the efficiency of the U.S. banking industry: Further Evidence. Journal of Business Finance \& Accounting, Vol. 35, No. 7, 2008, 50-70.

[5] Andrade, G., Mitchell, M., Stafford, E. New evidence and perspectives on mergers. Journal of Economic Perspectives, Vol. 15, No. 6, 2001, $103-120$.
[6] Andreou, P. C., Louca, C., \& Panayides, P. M. (2012). Valuation effects of mergers and acquisitions in freight transportation. Transportation Research Part E, 48(6), 1221-1234.

[7] Arikan, A. M \& Stulz, R. M. Corporate acquisitions, diversification, and the firm's life cycle. The Journal of Finance, Vol. 71, No. 31, 2016, 139-194.

[8] Banerje, A \& Eckard, E. W. Are megamergers anticompetitive? Evidence from the first great merger wave. Rand Journal of Economics, Vol. 29, No. 10, 1998, 803-827

[9] Bhabra, S. H., \& Huang, J. An empirical investigation of mergers and acquisitions by Chinese's listed companies. Journal of Multinational Financial Management, Vol. 23, No. 3, 2013, 186-207.

[10] Braguinsky, S., Mityakov, S., \& Liscovich, A. Direct estimation of hidden earnings: Evidence from Russian administrative data. Journal of Law and Economics, Vol. 57, No. 2, 2014, 281-319.

[11] Chang, S. C., \& Tsai, M. T. Long-run performance of mergers and acquisition of privately held targets: Evidence in the USA. Applied Economics Letters, Vol. 20, No. 6, 2012, 520-524.

[12] Chatfield, H. K., Dalbor, M. C., Ramdeen, C. D., \& Harrah, W. F. Returns of merger and acquisition activities in the restaurant industry. Journal of Food service Business, Vol. 14, No. 3, 2011, 189-205.

[13] Chatterjee, S. Types of Synergy and Economic Value: The impact of acquisitions on merging and rival firms. Strategic Management Journal, Vol. 10, No. 4, 1986, 119-139. 
[14] CAMA. Companies and Allied Matters Act, Lagos: The Federal Government Press 2004

[15] DeYoung, R., Evanoff, D.D., Molyneux, P. Mergers and acquisitions of financial institutions: A review of the post2000 literature. Journal of Financial Services Research, Vol. 36, No. 20, 2009, 87-110.

[16] Drees, M. J. (Dis)aggregating alliance, joint venture and merger and acquisition performance: A meta-analysis. Advances in Mergers and Acquisitions, Vol. 13, No. 4, 2014, 1-24.

[17] Frederikslust, R. A. I., Der Wal, V., \& Westdijk, H. Shareholder wealth effects of mergers and acquisitions. Milan Paper No. 262, 2008

[18] Figueira, C., Nellis, J., \& Parker, D. Banking performance and technological change in non-core EU countries: A study of Spain and Portugal. Studies in Economics and Finance, Vol. 26, No. 3, 2009, 155-170.

[19] Fowler, K. L. \& Schmidt, D. R. Determinants of tender offer postacquisition financial performance. Strategic Management Journal, Vol. 10, No. 2, 1989, 339-350.

[20] Ghatak, A. Effect of mergers and acquisitions on the profitability of India pharmaceutical. Research Journal of Social Science \& Management, Vol. 2, No. 6, 2012, 131-138.

[21] Gugler, K., Mueller, D.C., Yurtoglu, B.B., \& Zulehner, C. The effects of mergers: An international comparison. International Journal of Industrial Organization, Vol. 21, No. 8, 2002, 625-653.
[22] Huh, K. S. (2015). The performances of acquired firms in the steel industry: Do financial institutions cause bubbles? The Quarterly Review of Economics and Finance, Vol. 58, No. 2, 2015, 143 - 153.

[23] Ikpefan O. A. \& Kazeem B. L. O. The effect of merger on deposit money banks performance in the Nigerian banking industry. Journal of Applied Finance \& Banking, Vol. 3, No. 4, 2013, 105-123.

[24] Ikpefan, O. A. Post-consolidation effect of mergers and acquisitions on Nigeria deposit money bank. European Journal of Business and Management, Vol. 4, No. 16, 2012, 151 - 162.

[25] Indhumathi, G., Selvam, M., \& Babu, M. The effect of mergers on corporate performance of acquirer and target companies in India. The Review of Financial and Accounting Studies, Vol. 4, No. 1, 2011, 14-40.

[26] Investment and Securities Act. Investment and Securities Act Report, Lagos: The Federal Government Press, 2007

[27] Isibor A, Olokoyo F, Maria A,Osuma GO, Chisom N, Exchange rate management and sectoral output performance, International Journal of Supply Chain Management, Vol.7 No.5, 2018, pp. 129-134

[28] Isibor, A., Ojo, J.A.T., and Ikpefan,O. A. Does financial deregulation spur economic development in Nigeria? Peer-Reviewed Proceedings of the International Business Information Management Association Conference ( $31^{\text {st }}$ IBIMA) held on $25-26$ April 2018, Milan, Italy.

[29] Joshua, O. Comparative analysis of the impact of mergers and acquisitions on financial efficiency of banks in Nigeria. Journal of Accounting and Taxation Vol. 3, No. 1, 2011, 1-7. 
[30] Kandzija, V., Filipovic, D., \& Kandzija, T. Impact of industry structure on success of mergers and acquisitions. Tehnicki VjesnikTechnical Gazette, Vol. 21, No. 2, 2014, 1725.

[31] Kemal, M. U. Post-merger profitability: A case of Royal Bank of Scotland (RBS). International Journal of Business and Social Science, Vol. 2, No. 5, 2011, 157 - 162.

[32] Leepsa, N. M., \& Mishra, C. S. Post merger financial performance: A study with reference to select manufacturing companies in India. International Research Journal of Finance and Economics, Vol. 1, No. 83, 2012, 6-17.

[33] Lipson, L. M., \& Mortal, S. Liquidity and firm characteristics: Evidence from mergers and acquisitions. Journal of Financial Markets, Vol. 10, No. 4, 2007, 342-361.

[34] Moeller, S., Schlingemann, F., \& Stulz, R. Firm size and the gains from acquisitions. Journal of Financial Economics, Vol. 73, No. 37, 2004, 201-228.

[35] Mulherin, J., Boone, A. Comparing acquisitions and divestitures. Journal of Corporate Finance, Vol. 6, No. 3, 2000, 117 $-139$.

[36] Ngojo B. O., Ayanwale S. \& Nwankwo E. Impact of mergers and acquisitions on the performance of deposit money banks in Nigeria. European Journal of Accounting, Auditing and Finance Research, Vol. 4, No. 4, 2016, 105-123.

[37] Pandit, S., \& Srivastava, R. Valuation in merger process. Journal of Teaching and Education, Vol. 5, No. 1, 2016, 361-370.
[38] Poornima, S., \& Subhashini, S. Impact of mergers and acquisitions across industries in India. International Journal of Management Research and Development, Vol. 3, No. 2, 2013, 113-125.

[39] Ramaswamy, K. \& Waegelein, J. Firm financial performance following acquisitions. Review of Quantitative Finance and Accounting, Vol. 20, No. 9, 2003, 1323.

[40] Sharma, S. Measuring post merger performance: A study of metal industry. International Journal of Applied Research and Studies, Vol. 2, No. 8, 2016, 20-35.

[41] Singh, F., \& Mogla, M. Profitability analysis of acquiring companies. IUP Journal of Applied Finance, Vol. 16, No. 5, 2010, 72-90.

[42] Umoren, A.O \& Olokoyo, F.O. Merger and acquisition in Nigeria: Analysis of performance of pre and post consolidation. Journal of Banking, Finance and Economic Issues, Vol. 1, No. 1, 2007, 1 - 13.

[43] Usman, A., Mehboob, Ullah, A., \& Farooq, S. U. Relative operating performance of merged firms in Pakistan. European Journal of Economics, Finance and Administrative Sciences, Vol. 11, No. 20, 2010, 44-48.

[44] Vanitha, S., \& Selvam, M. Financial performance of Indian manufacturing companies during pre and post merger. International Research Journal of Finance and Economics, Vol. 15, No. 12, 2007, 7-35.

[45] Weston J. F, Mitchell M. L, \& Mulherin J. H. Takeovers, Restructuring, and Corporate Governance. Fourth Edition, New Jersey, NJ: Pearson Prentice Hall, 2004 
[46] Menyelim Chima, Abiola Babajide, Alexander Omankhanlen, Babafemi Adejumo, Development: Unconventional Monetary Policy on Bank Performance in Nigeria, WSEAS Transactions on Environment and Development, pp. 844-860 Volume 16, 2020

[47] Ekanem Thelma, Rotimi Olatunji, Lanre Amodu, Oscar Odiboh, David Imhonopi,Nomenclature and Functions of Corporate Communication Units of Nigerian Universities: A Comparative Examination, WSEAS Transactions on Environment and Development, pp. 784-793, Volume 16, 2020

[48] Inese Mavlutova, Kristaps Lesinskis, Mindaugas Liogys, Janis Hermanis, Innovative Teaching Techniques for Entrepreneurship Education in the Era of Digitalisation, WSEAS Transactions on Environment and Development, pp. 725-733 Volume 16, 2020

\section{Creative Commons Attribution License 4.0 (Attribution 4.0 International, CC BY 4.0)}

This article is published under the terms of the Creative Commons Attribution License 4.0

https://creativecommons.org/licenses/by/4.0/deed.en_US 